\title{
JOHN DRYDEN, RESTORATION, AND NEOCLASSICISM: SAMPLES OF PRESCRIPTIVE CRITICISM IN ENGLISH LITERATURE
}

\section{Petru GOLBAN ${ }^{1}$}

\begin{abstract}
Özet: Edebi eleştiri, amacı belli çalışmaları analiz etmek olmakla beraber, edebi metni değerlendirme ve anlama entelektüel yetisi anlamına da gelir; fakat birçok eleştirmen 20. Yüzyıldan önce bunu başarmış olmasına ragmen, İngiliz geçmişinde eleştiri, eleştirel eylemin doğasına yabancı bazı nedenlerle başlamıştır. Örneğin, Sydney savunur, Dryden öngörür, Pope düşünür ve öngörür, Fielding yeni bir tür ve Wordworth yeni bir şiir çeşidi tanıtır vb. Neoklasik dönemde İngiliz eleştirisi karmaşık ve çok sesli bir olguydu ve normatif bir eleştirel söylem geliştiren yazar vey azar-eleştirmenler tarafindan temsil ediliyordu. John Dryden ve "Of Dramatic Poesi" denemesi Restorasyon dönemi İngiliz eleştirisinin durumunu daha iyi gösterecekti. 18. Yüzyılın ilk yarısına Alexander Pope'un "An Essay on Criticism and An Essay on Man"inde ifade edilen neoklasik fikirler yön vermişti. Ikinci yarısı, Dr. Samuel Johnson'ın karakteri ve Influential Lives of the Poets and Dictionary of the English Language adlı ederi tarafından yönlendirilmişti. İngiliz Edebiyatında neoklasik döneme ait en öngörülü eleştirel ses, John Dryden'ınkiydi ve Alexander Pope da ona eşlik ediyordu. Bu çalışmanın amacı, Dryden ve Pope'un eleştirel söylemleri bağlamında, öngörü ve eleştirinin özünü, edebiyatı açıklayarak ona yön vermesi olarak ortaya çıkarmaktır.
\end{abstract}

Anahtar Sözcükler: Restorasyon, Neoklasizm, Edebiyat Eleştirisi, Edebiyat Kuramı, Eleştirmen, Yazar-Eleştirmen.

\section{Introduction}

In English literature, neoclassicism is a period of literary history covering the last part of the seventeenth century throughout the eighteenth century; neoclassicism is a movement in literature with its poetic works and a strongly normative and prescriptive doctrine; and also neoclassicism is the creator of a particular trend in poetry, philosophical and satirical.

English literature of the last decades of the seventeenth century and most of the eighteenth century, or, more precisely, the period from 1660s to 1780s (that is, from Restoration to the rise of Romanticism), was dominated by classical doctrine that continued and institutionalised the revival of ancient classical tradition that had started in Renaissance.

\footnotetext{
${ }^{1}$ Doç. Dr., Namık Kemal Üniversitesi, Fen-Edebiyat Fakültesi, İngiliz Dili ve Edebiyatı Bölümü. pgolban@nku.edu.tr
} 
The new classical doctrine - which is referred to as "neoclassicism" prescribed styles and rules of writing to writers and ways of critical thinking to literary scholars of the period, thus promoting the dependence of literature upon the ancient models. The leading country in Europe, both politically and culturally, France became the source of spreading the classical ideas to other countries, including Britain, pleading for what is natural and reasonable, and for rules, order, clarity, measure, sense of proportion, and good taste. On the general social level, following the "Glorious Revolution" of 1688 and the 1707 "Act for a Union of the Two Kingdoms of England and Scotland", Britain steadily embarked on the path of progress and prosperity based on the idea of order and proportion. The nation acquired a sense of stability and selfconfidence, where

an ideal of providential harmony, of co-operation, and of a political order reflecting that of nature seemed to many to be realized in the triumph of practical reason, liberal religion, and impartial law. Temperate kings would reign over a united nation in which individual liberty would be constitutionally guaranteed (Sanders, 1994, p. 277).

Based on ancient tradition and classical values, neoclassicism is the dominant theory of the period, whose corresponding literary practice includes satirical and philosophical poetry. It would influence not only the contemporary poetry and the consolidation of the novel writing tradition in the eighteenth century, but also the later Victorian realism with its novels of the socially concerned, realistic, traditional, normative, and moral type.

Coinciding with and corresponding to the general European "Age of Enlightenment", neoclassicism, its literary version in English cultural background, is considered as a period of literary history dating from 1660s to 1780s and as consisting of three parts: (1) the "Restoration Age" (1660-1700), or the "Age of Dryden", followed by (2) the "Augustan Age" (1700-1750s), or the "Age of Pope", and by (3) the "Age of Johnson" (1750s-1780s) which coincides with the "Age of Sensibility", both reflecting the decline of the neoclassical period.

Starting with the weakening of neoclassicism by the mid-eighteenth century, Pre-Romanticism would mark the transition of literature from the neoclassical to the Romantic period. The rise of the novel (with its realistic element, moral didacticism, and comic features) would signify the consolidation of an almost entirely new genre in English literature, that of imaginative prose, as well as the later flourishing of fiction, both novel and short story, in Victorian and later periods. Pre-Romanticism was a trend in poetry ("primitive" and "mournfully reflective") which manifested as an alternative to neoclassical poetry and as a precursor to Romanticism, without developing important critical theories. On the contrary, neoclassicism embraced both theory and literary practice, and many of the founders of the English novel expressed critical views on the newly rising genre. 


\section{The Literary Criticism of the Seventeenth Century in General European Context}

Following the period of Baroque, the seventeenth century further extended the direction of classicism in European practice and theory of art. Classicism as the most important cultural aspect of the century owes its critical relevance to the major French thinkers of the period. Among them, Francois de Malherbe and Michel de Montaigne seeking to achieve the purification of native language for clear communication, and Chapelain, Corneille, d'Aubignac, Bouhours, Rapin, and Boileau, the last three, especially, as the real founders of the classical, in English studies also referred to as "neoclassical", theory. The word "classical", however, dates from the eighteenth century with reference to ancient authors (Sophocles, Cicero, Terence, etc.) who serve as models, as well as to some seventeenth century writers (Boileau, Racine, Corneille, Moliere, etc.) who imitated the ancient models, followed the rules of composition, whose style is "correct" and elegant, and who thus also came to be labelled as "classics". The term "classicism" was originally used in the first decades of the nineteenth century (presumably by Stendhal in 1823), at first pejoratively, as it was the age of Romanticism, to denounce a type of literature that seemed obsolete and useless, and then positively (as by Goethe in 1829) and finally laudatory with the meaning of "eternity" and "perfection". Likewise, the adjective "classical" refers to ancient Greek and Roman and later to seventeenth and eighteenth century European art and literature (corresponding to the term "neoclassical" used for English literature), but it is also synonymous to "perfect" and "eternal". Regarding the literary practice in the seventeenth century, Europe was dominated mainly by French authors, namely by Racine, Corneille, Moliere, La Fontaine, Boileau, and others who reacted against the cultural extravaganza of the Baroque and institutionalized classicism. Concerning the literary genres, towering over the entire period is drama, in determent of other existing genres (lyrical poetry, narrative poetry, novel, novella, short story, fable, etc.). Within drama, in determent of other dramatic forms (comedy, tragic-comedy, historical play, dramatic pastoral, and others), the dominant type of text was tragedy. The public would ask for fidelity to actuality in its textual and scenic representation, and the classical tragedy, conceived as mimesis, "behaves towards external reality with certain faithfulness which other genres are not able to achieve" and

From Sophocles and Euripides to Racine and Goethe, Claudel and Ibsen, O'Neill and Durrenmatt, the tragedy, drama, and tragic farce take place in some clearly defined time and place, which point to the history and ethnography of a civilization, and to a geography of a place that can be recognized (Munteanu, 1989, p. 139).

The predominance of classical tragedy in the seventeenth century emerged also from the demands of the public concerning rules and common sense, and as supported and encouraged by Richelieu. Another reason for the supremacy of tragedy was the important theoretical input - about unities, rules, good taste, reason, and other aspects related to tragedy - which was provided, first, in 1639, 
by La Mesnardiere (in Poetique) and Jean Francois Sarasin (in Discours sur la tragedie), and later by Racine and Corneille, among others. The word "tragedy" was familiar to French people already at the end of the sixteenth century, but its meaning referred to an epic narration of cruel and murderous events. Only later the term came to name a particular dramatic form. Also, as inherited from the ancients, namely from Aristotle's Poetics, tragedy was labelled "tragic poem", not "tragedy" like nowadays, meaning that in the seventeenth century, and "unlike today, drama and poetry were not totally distinct genres" (Clement, 2000, p. 15). Coming from Greek "goat song", it is agreed among the scholars that the term "tragedy" originally "denoted a form of ritual sacrifice accompanied by a choral song in honour of Dionysus, the god of the fields and the vineyards. Out of this ritual developed Greek dramatic tragedy" (Cuddon, 1992, p. 983).

The most discussed topic in relation to drama was its form rather than thematic level, including action, situation, convention, character, conflict, language, dialogue, and other aspects of the structural level. Concerning character, for instance, the ancient heroes were revived but also new myths were created, such as those of Don Juan and Faust. French classicism conceived of character by "revealing a dominant, a feature which is fundamentally human and around which all the other features are structured. It could be avarice, pride, honour, snobbism, or folly" (Ceuca, 2002, p. 45-46). Regarding the verbal discourse in drama, the French classicism "follows concision and eloquence, but also the soundness of the verse"; later, "in Romanticism, there will be imagism, metaphor, comparison, epithets. Realism brings language close to a common usage and imposes prose instead of verse" (Ceuca, 2002, p. 44).

Among the major representatives of the seventeenth century classicism, Pierre Corneille (1606-1684) and Jean Racine (1639-1699) were primarily tragedians. Moliere (Jean-Baptiste Poquelin, 1622-1673) was the greatest master of comedy, but who initially wanted to become a tragic author and actor. It is said that Moliere turned to comedy "only after the failure of his single tragedy (Dom Garcia de Navarra), and would admit comedy as a "major" genre only after ascribing to it the rules of tragedy" (Clement, 2000, p. 9). Jean de La Fontaine (1621-1695) was a major fabulist and poet. Nicolas Boileau-Despreaux (16361711) and Rene Rapin (1621-1687) dominated the age as poets and critics. Apart from Boileau and Rapin, the literary theory and criticism of the seventeenth century owes its significance also to Racine and Corneille. The former expressed his ideas, revealing obedience to classical rules and being mainly concerned with the history and nature of tragedy, in a series of prefaces. The latter develops his ars poetica in three "Discourses" written for the publication in 1660 of his complete works, in which the main concern is again tragedy, discussed in all its aesthetic, historical, and moral dimensions. Corneille starts from ancient theories, but reformulates the notions related to the three "unities", formulates new concepts (such as "suspension" and "preparation"), redefines "exposition", prefers complex action and favours 
characters that display energy, personality, and free choice. In particular in $O f$ the Three Unities of Action, Time, and Place (1660) Corneille established the neoclassical theory of drama which was followed by Dryden. Many of his principles are valid nowadays, especially in the traditional drama. Racine also gives importance to the free decision of the hero but accepts the omnipresence of destiny and, like Corneille, shows the failure of man to dominate events. For Racine, there is a superior, cruel force that controls the events and the only resolution is death. Unlike Corneille, Racine favours the simplicity of action and emphasises the thematic efficiency of psychological and emotional states, as in the Preface to Britannicus: the action must be "simple, with as less as possible material (...) to be sustained only by the feelings and passions of the characters".

The tutelage for the critical theory of the period was provided by the French Academy, founded by Richelieu in 1634. The guiding principles of the critical theory were borrowed from Antiquity, namely from the works of Aristotle and Horace, whose influence was decisive and whose texts were frequently translated and commented starting with the middle of sixteenth century. The ancient theoretical texts were revived; or rather there was a continuation of the revival of ancient classical tradition which started in the Renaissance. The ideas from the texts were assumed but also debated on and even modified or rejected.

On the whole, starting from these ancient texts, the seventeenth century theoreticians developed a new "classical" doctrine which was expressed in different treaties, prefaces and advertisements. The doctrine itself might be considered a wholly new literary genre, but this idea is thwarted by the wide range of theoretical concerns with rules, models, reason, rigour, clarity, common sense, moral and didactic values, catharsis, mimesis, verisimilitude, character, subject-matter, tragic and comic elements, structure of the dramatic text, and the unities of time, place, and action. In this age of old and new rules, the only unquestionable voice was that of Aristotle, whose Poetics would often be evoked to validate or reject whatever matter related to the form and content of the literary text.

On a more general philosophical level, the seventeenth century was governed by the works of Bacon, Galileo, Hobbes, Descartes, Pascal, Spinoza, Leibniz, and others who made it an age of reason, marking the rise of physical sciences and of empirical, experimental methods, and thus proclaiming the reign of mind and rationalism. The new scientific spirit of the seventeenth century proclaims its independence from the religious norms first through the work of Galileo Galilei (1564-1642). A similar endeavour was made earlier by Nicolaus Copernicus (1473-1543) who opposed the medieval view of the universe by his new heliocentric theory. By his improvement and use of telescope and his astronomical studies, Galileo extended further the scientific revolution and determined new directions in philosophical thinking, which proclaimed the autonomy of the scientific reasoning and argument against the dominant views of the Holy Books: 
Galileo produced an epistemological revolution: he not only desacralised the sky, making of telescope an instrument of discovery which allows the scientist not to search for truth in old books, but especially conferred to the truth a new status, defining it rigorously as being the exact essence of the mathematical calculation applicable to the entire nature (Graf, 1997 p. 6).

Blaise Pascal (1623-1662), continuing Galileo's epistemology, also advocates the separation between the scientific truth and religious obedience, and opposes the "God of philosophers and scientists to the God of the Bible". For Pascal, as for others philosophers, the reason is the principal faculty of acquiring knowledge, possessing the capacity to judge the natural objects without any help from imagination or feeling. Every natural phenomenon, argues Pascal, can be explained by the power of reason, but he seems to reconcile rationalism with theology, since he accepts the miracle and considers it to be an event revealing the power of God to act upon nature to disturb the natural forces. The miracle provides exceptions in the work of reason and remains beyond human understanding.

Unlike Pascal, Baruch Spinoza rejects the existence of miracles whatsoever. Another rationalist of the seventeenth century philosophy and a forerunner of the eighteenth century Enlightenment, Spinoza is the only thinker of the period who "takes the mechanicalism to its last consequences, formulating a radical criticism on metaphysics: nothing, not even the human being, surpasses nature" (Graf, 1997: 13). Apart from the natural sciences, the opposition to religious views manifested in the seventeenth century also in the field of social and political philosophy, as in the works of Cyrano de Bergerac (1619-1655) and Bernard le Bouyer de Fontennelle (1657-1757).

The most popular thinker in this respect was Thomas Hobbes (1588-1679) who, proving scepticism and materialism in his political philosophy, suggests a strong secular state in Leviathan (1651). In this work, Hobbes "tried to build a philosophy of mind, using solely the facts of memory and imagination. Reasoning is mere calculation, the manipulation of signs, and the reasoning is correct if the same signs are constantly attached to the same images" (Hampshire, 1956, p. 35).

Hobbes's ideas were highly influential throughout Europe during the age of Enlightenment, which owes actually much of its theoretical input to the ideas expressed in the seventeenth century in the writings of Hobbes as well as Newton, Pascal, Leibniz, Galileo, and especially of empiricists and rationalists, namely John Locke's and Rene Descartes's philosophical works.

Actually, rationalism and empiricism were the most important and at the same time countervailing philosophies of the seventeenth century, the former emphasising reason and innate ideas, whereas the latter highlighting experience and rejecting tradition and innate knowledge. The work entitled Essay Concerning the Human Understanding (1690) by John Locke (1632-1704), with its concern with the foundation of human knowledge and understanding, and the 
theory of the human mind/spirit as tabula rasa ("blank slate") filled later through the experience, represented one of the main sources of the empiricist school of thought in modern philosophy. Empiricism departs radically from the rationalism of Descartes, but it influenced many British Enlightenment philosophers, such as David Hume and George Berkeley, and many writers and theoreticians of neoclassicism, such as Alexander Pope and Samuel Johnson. It also influenced the men of letters in later periods, such as William Wordsworth in whose poetry the development of the human/poet's mind is a major thematic perspective. It was not until the twentieth century that Locke's doctrine was rejected by Carl Jung and other philosophers who developed new theories of the abstract manifestations of the mind, pre-established forms of psychic behaviour, collective memory and archetypes.

Empiricism, typical to Great Britain philosophy, opens with Francis Bacon, the guiding spirit of the scientific revolution, writing on all the sciences, philosophy, politics, law, ethics, and other topics, a total of more than seventy works. In The Advancement of Learning, dedicated to King James I, Bacon expresses his belief in the perpetual renovation of knowledge, and argues that "science can no longer be derived from the books of Aristotle and Pliny but must result from first-hand observation and experiment. Instead of being isolated, scientific disciplines should cross-fertilize each other" (Vickers, 1996: 163). Bacon declares science to be the greatest force and the experience to be the only foundation of science. It implies the acquiring of knowledge through the inductive method, which is outlined in the Novum Organum and which means the development of general laws starting from the observation of particular facts. This new method of scientific thinking, argues Bacon, would be "free of the prejudices of the past and the received affections of the present (characterised as the "Idols" of the Tribe, the Cave, the Market Place, and the Theatre)" (Sanders, 1994, p. 189).

Opposed by empiricism, but of equal value, was the influence of the philosophical work of René Descartes (1596-1650), also known as Renatus Cartesius (the Latinized form of his name). A highly influential French philosopher, scientist and mathematician, Descartes represents together with Baruch de Spinoza and Gottfried Leibniz the seventeenth century European rationalism. Descartes's most important philosophical writings are Discourse on Method (1637), Meditations on First Philosophy (also known as Metaphysical Meditations, 1641), and Principles of Philosophy (1644). In his philosophical work, in particular in Meditations on First Philosophy, Descartes aims at developing a fundamental set of principles that one can know as true without any doubt. The method employed is the so-called "methodological scepticism", by which he rejects any idea that can be doubted in order to acquire a firm foundation for genuine knowledge. The only unshakable knowledge is that man is a "thinking thing". Thinking is the essence of the human being, as it is the only aspect about him that cannot be doubted and the only activity of which he is immediately conscious of. Descartes defines cogitatio ("thought") as "what 
happens in me such that I am immediately conscious of it, insofar as I am conscious of it". By what is known as the "wax argument", Descartes shows the limitations of the senses and proves that one should use his mind to properly grasp the nature of an object or phenomenon, concluding that "what I thought I had seen with my eyes, I actually grasped solely with the faculty of judgment, which is in my mind". In his system of knowledge, Descartes rejects the sensory perception as unreliable and admits deduction and reason as the only reliable methods of attaining knowledge that takes the form of ideas, and the philosophical investigation is the contemplation of these ideas. The first item of undoubtable knowledge that Descartes argues for is cogito, or thinking thing, and the first principle Descartes arrives at is one of his most famous statements, which is cogito ergo sum ("I think, therefore I am"). Other famous statements by Descartes are ex nihilo nihil fit ("nothing comes out of nothing") and dubium sapientiae initium ("doubt is the origin of wisdom").

At the time when Descartes discovered rationalism, reason, cold calculation, mind, and the consciousness of ego cogito, there were voices that turned to heart and feeling, as Pascal did by discovering "the logic of the heart as over against the logic of calculating reason" (Heidegger, 1971, p. 127). Indeed, Blaise Pascal, mainly acclaimed as mathematician, physicist, and philosopher, is also remembered for having opposed both rationalism and empiricism. By contrast to them, in order to determine the major truths in life, Pascal suggests a system in which, according to Heidegger,

the inner and invisible domain of the heart is not only more inward than the interior that belongs to calculating representation, and therefore more invisible; it also extends further than does the realm of merely producible objects. Only in the invisible innermost of the heart is man inclined toward what there is for him love: the forefathers, the dead, the children, those who are to come (Heidegger, 1971, p. 127-128).

Due to his philosophical system based on the method of systematic doubt, Descartes is called the founder of the modern theory of knowledge, and as such he influenced much of his contemporary and of the later periods European philosophical thought, starting from Spinoza to Russell.

Although accepting the influence of some earlier Jewish philosophy, many scholars have considered the philosophical work of Baruch de Spinoza (16321677) to be the continuation or the further development of Descartes. Indeed, the only work published during his lifetime, Principles of Descartes's Philosophy is an exposition of Descartes's philosophy in geometrical order. Spinoza has been acclaimed by some and condemned by others for his Ethics, a philosophical book published after his death, which, although rooted in many of Descartes's conclusions, is in many respects a rather original work presenting Spinoza's own thought. Rationalist, rigorous, deductive, and materialist, Spinoza develops his own metaphysical system, his own views of Cod, creation, nature, structure of the world, idea and body, mind and matter, cause and 
substance, and above all, his moral doctrine aimed at salvation of man and the nature of society.

Another seventeenth century philosopher who studied and assimilated Descartes's philosophy was Gottfried Wilhelm von Leibniz (1646-1716). In his work, one finds the same emphasis on reason and rationalism, the principle of order, the similarity between logic and mathematics, and the connection of his metaphysics with his logic, which is the great merit of his philosophical system. The distinction between two types of statements is at the centre of Leibniz's philosophy: first, those which are necessarily true and established as true only by reference to the principle of non-contradiction, and, second, those called "contingent statements", which cannot be established as true by the principle of non-contradiction alone. Also, at the centre of Leibniz's system is the attempt to define such concepts as Identity, Subject, Necessity, Truth, Knowledge, Existence and others. The discussion of these notions is organized in such a way as

to allow a place for a benevolent God who has freely created a world which is entirely intelligible. The world that God has created must exhibit a few universal principles of order, which ought to guide us in framing hypotheses to explain phenomena; for we have in metaphysics an assurance that the actual world is the most rationally ordered of all possible worlds (Hampshire, 1956, p. 146).

In the same way, Alexander Pope, the most important representative of English neoclassicism in the eighteenth century, would declare in his An Essay on Man that the actual world is perfect in its rational organization and that humans fail to see its perfection due to their limited vision.

English neoclassicism was mainly influenced by French ideas of the period, France being actually the country that institutionalized classicism in the second half of the seventeenth century and became the most important cultural influence in Europe. Thus, apart from theoretical input from both empiricists and rationalists, both John Locke's and Rene Descartes's philosophical works, as well as of Bacon, Hobbes, Spinoza, and Leibniz, of equal importance to the consolidation of the neoclassical doctrine in Britain were the leading French ideas from, among others, L'Art Poetique (1674) by Nicolas BoileauDespréaux, commonly called Boileau, and Réflexions sur la poétique d'Aristote et sur les ouvrages des poétes anciens et modernes (1674) by Rene Rapin. Rapin's work was translated into English by Thomas Rymer (1641-1713), himself a man of letters who in the Preface to the translation exalts Aristotelian rules and defends the neoclassical position. Also by reference to ancient models, Rymer performs a more textual examination of the works of Fletcher and Beaumont, in The Tragedies of the Last Age (1678), and later of Shakespeare. It is his view that Shakespeare's Othello might be improved if the words are left out that made Rymer be rejected by fellow-writers and receive harsh replies, as from the contemporary satirical poet Samuel Butler (1613-1680). Another reply to Rymer, this time to his Short View of Tragedy, came from John Dennis (1657-1734) in The Impartial Critic (1693). In the general context of the 
period's reverence for the classics, Dennis argues that a "strict adherence to Greek practices which were closely linked to the religious and cultural notions of the day would be an absurdity in modern drama" (Blamires, 1991, p. 122). Sir William Temple (1628-1699) in Miscellanea, Of Poetry (1690) and William Wotton (1666-1726) in Reflections Upon Ancient and Modern Learning (1694) also acclaim the achievements of the ancients but exhibit a certain degree of reserve regarding their strict imitation and the total dependence of modern literature on them. The blind admiration for the classics must be replaced by a true, more rational appreciation of their works. Also, Temple replies to the "rigid claims for the Aristotelian rules made by French critics such as Boileau and Rapin" and argues that the most "that can be claimed for rules is that they might prevent some men from becoming bad poets without helping anyone to become a good one. It is by the power of the poet to work on your feelings that can be judged." (Blamires, 1991, p. 112)

According to Edgar Allan Poe, Boileau is a "French Horace", and indeed the classical views of Boileau and Rapin are anything but original. Their ideas are largely an extension of those of Horace and Renaissance critics, but Boileau and Rapin express an attitude of measure, common sense, reverence for rules, the concepts of "human nature" and "decorum", imitation of the ancient poets, and worship of reason better than anyone in the period, as Boileau states in his Art of Poetry:

Whatever you write of pleasant or sublime,

Always let sense accompany your rime;

Falsely they seem each other to oppose, -

Rime must be made with reason's laws to close;

And when to conquer her you bend your force,

The mind will triumph in the noble course; (...)

Love reason then, and let whatever you write

Borrow from her its beauty, force and light.

The Art of Poetry has remained one of the best known works of critical writing, especially where and when the classical spirit is concerned and promoted. All the main tenets of the neoclassical doctrine are to be found here, including the ideal of reason, strict rules of composition, decorum, urbanism, didacticism, and above all the imitation of the ancients, who portrayed human nature in the best possible way.

However, the seventeenth and eighteenth centuries saw classicism being attacked by the "moderns", who challenged the view that writers should admire and imitate the great ancient Greek and Latin models because civilization had not produced anything better or more excellent to surpass the great classical tradition. The main arguments of the moderns against the rule of the classics, as set forth and explained by Gilbert Highet, are (1) "the ancients were pagan; we are Christians. Therefore our poetry is inspired by nobler emotions and deals 
with nobler subjects. Therefore it is better poetry"; (2) "Human knowledge is constantly advancing. We live in a later age (...) therefore we are wiser. Therefore anything we write, or make, is better than the things written and made by the ancient Greeks and Romans"; (3) "Nature does not change (...) therefore the works of men are as good to-day as they were in classical times"; and (4) the works of the classics "were badly written and fundamentally illogical" (Highet, 1976, p. 261-288).

The attacks on art and literature of the classical writers agitated the spirits of the literary world and initiated the conflict between the defenders of the classics (Dacier, Racine, Boileau), who created a deeper understanding of ancient literature and expanded the literary traditions of the Renaissance, and the "moderns" (Tassoni, de Saint-Sorlin, Perrault), who argued that modern literature possesses aesthetic values as high as those of the classical Greece and Rome.

The conflict is remembered as "the battle of the books" and "la querelle des anciens et des modernes". It is just one battle in the war between innovation and tradition, between originality and authority, between classicism and modernism. The war started in Antiquity, was reinforced in the Renaissance, peaked in France and then throughout Europe at the turn of the seventeenth century and is still going on. In English literature, this conflict was remarkably captured by the neoclassical man of letters Jonathan Swift (1667-1745) in his satire on the battle between ancients and moderns known as The Battle of the Books (1704).

\section{English Literature and Literary Criticism in Restoration}

Concerning English critical thought of the period, the outcomes of the conflict in the seventeenth and eighteenth centuries were also beneficial for the development of literary criticism, whose standards improved, and ideas, though sharpened, became more refined. According to Marcie Frank, in the seventeenth century "criticism arises in response to the seventeenth century series of crises in aristocratic culture, and its historical orientation marks its contributions to the modern separation of literature as autonomous from political, legal and historical discourses." But there is no separation whatsoever between literature and criticism. Like in the previous century, the seventeenth century criticism remains inseparable from literature, especially from the drama of the period, as "together, both literary and critical discourses seek to distinguish themselves from the body of discourses that share a deep investment in the institution of genealogical inheritance as an authorizing and legitimating activity even as they also rely upon them" (Frank, 2002, p. 13). However, after Sidney there were, unfortunately, no important critical voices to assess the great literary achievements of the Elizabethan and Jacobean periods, and it was only with John Dryden that English literary criticism stood firmly again on its path.

Meanwhile, the history of criticism mentions John Milton (1608-1674) defending poetry and theatre, and the liberty of printing in general, against Puritan attacks, during Commonwealth periods in Areopagitica. Mention should 
be also made of an earlier critical endeavour, namely Ben Jonson's (1573-1637) emphasis on rules and decorum in the prologues written to his many plays and in the book Timber, or Discoveries (1640). Here Jonson speculates also on Shakespeare and his literary achievement, praising him but also entering polemics on behalf of the newly emerging neoclassical perspectives of measure and common sense: "He [Shakespeare] was (indeed) honest, and of an open, and free nature: had an excellent Phantasy; brave notions, and gentle expressions: wherein he flow'd with that facility, that sometime it was necessary he should be stopp'd".

The history of criticism also mentions a verse survey of English poets by Michael Drayton (1563-1631) entitled Epistle to Henry Reynolds, Esquire, Of Poets and Poesie (1627). Reynolds himself is the author of Mythomystes, Wherein a Short Survey is taken of the nature and value of true Poesie, and depth of the Ancients above our Modern Poets (1632). Other critics were the royalist refugees in Paris, among whom philosopher Thomas Hobbes and the writers Sir William Davenant (1605-1688) and Abraham Cowley (1618-1667). They came under French influence and contributed in their turn to the development of native critical theories. The most important seventeenth century English critic was John Dryden, of whose many literary and non-literary works the most famous one is the critical treatise Of Dramatic Poesie, An Essay, written in dialogue form and derived from Dryden's own practical experience as a playwright in many areas of drama.

In English literary history, the last period of the seventeenth century was the "Restoration Age" between 1660 and 1700, which followed the Puritan rule ("Commonwealth Interregnum") between 1649 and 1660. On the general social level, the "English Renaissance, which had begun as an opening up to new European learning and to new European styles, ended as a restrictive puritanical assertion of national independence from European norms of government and aesthetics"; likewise, the "English Reformation, which had begun as an assertion of English nationhood under a monarch who saw himself as head, protector, and arbiter of a national Church, ended as a challenge to the idea of monarchy itself" (Sanders, 1994, p. 185). Following the abolition of monarchy and the subsequent Puritan period, the next period, which is called "Restoration", started from the restoration of the Stuarts (with Charles II) to the throne of England in 1660.

In literature and thought, the main representative of the Restoration period was John Dryden, the poet, the playwright and the theoretician of early neoclassicism, but the period had also Milton's Paradise Lost (1667), John Bunyan's Pilgrim's Progress (1658), and John Locke's Essay Concerning the Human Understanding (1690). The period also saw the foundation of the Royal Society in 1662, the re-opening of the theatres with the accession of Charles II, and the rebirth of arts and literature in general. On the general literary level, there are two main aspects usually brought into discussion. First, concerning the literary doctrine, Restoration was the period of the revival and 
institutionalization of the classical principles, which make Restoration represent the beginnings of neoclassicism in Britain. Second, concerning the literary practice, and due to the reaction against the rigid Puritan rules, Restoration literature was characterized by pleasure-seeking and valiant heroism, a kind of hedonistic atmosphere that manifested itself mainly in dramatic comedy, and became the stylized version of sophisticated upper class ethics in which elegance, abstractness, and wit represented the ideal of Restoration literature. Wit, in particular, which followed the refinement and sophistication of the court, became the reflection of a new respect for reason and clarity. Wit became also the criteria of judgement of the aesthetic value of the literary text, being defined by John Dryden, in the Preface to his poem Annus Mirabilis (1667), as "the faculty of imagination in the writer".

The main genre of Restoration literature was drama, which, written now by both men and women, was concerned with general human and social interests. It was represented mainly by comedies - plays generally designated as "comedy of manners" - most of which being French and Spanish adaptations, and some ridiculing the Puritans or provincialism. Although Restoration drama aimed at reviving the great Renaissance tradition, it changed its both thematic and formal perspectives. Also, "the actors changed, with young women acting the female parts for the first time", "the plays and the audience changed. The audience was now rich, upper-class, young, cynical, and fashionable, at least until the end of the century, and the plays were written to match this audience" (Stephen, 1984, p. 51).

The Restoration theatre was a cultural phenomenon of quick rise and fall, its major spokesman being John Dryden, out of whose twenty-eight dramatic works, the play entitled Marriage A-la-Mode (1672) is considered to be the most important and subtle in its social satire, revealing at best the Restoration attitudes towards youth and age, love and marriage, vanity and affection. Among other representatives of Restoration drama, mention should be made of Sir George Etherege (1634-1691) who, in The Comical Revenge, or, Love in a Tub (1664), She Would if She Could (1668), and The Man of Mode, or, Sir Fopling Flutter (1676), attempted to reveal the Restoration character with its conflicting ways of life, torn between wit and virtue, surrender to passion and desire for freedom. William Wycherley (1640-1716) in The Country Wife (1675) and The Plain Dealer revealed a critical spirit not entirely compatible with Restoration ethos, but reacting against tricksters and bullies, dishonesty, selfishness, cruelty, lust, and obsessive compulsion.

William Congreve's (1670-1729) Love for Love (1695) and The Way of the World (1700) granted him the status of the true master of the "comedy of manners" concerning both the character representation strategies and the sophistication of the plot construction in the dramatic expression of some of the dominant in Restoration thematic perspectives, such as the contrast between private behaviour and public reputation, strong emotion and artificial loyalty. 
Restoration comedy of manners is a type of realistic comedy that displays a witty, satiric atmosphere, laying emphasis on social commentary rather than characterization. The plot of the comedy of manners, elaborate, artificial, and often concerned with an illicit love affair, or some other scandal, is generally less important than the satire and the witty, epigrammatic, and often bawdy dialogue.

Apart from the comedy of manners, another type of play popular in Restoration, though it lasted only a short period during the 1670 s, was the "heroic drama", also called "heroic tragedy", developed by Dryden and followed by other writers, such as Sir George Etherege and Sir Robert Howard (1626-1698). The latter turns a critic in the prefaces to his plays initiating a controversy with Dryden especially over such a matter as blank verse or rhyme. Their interaction could be summarised in the following: Howard's 1665 preface to Four New Plays "replies to Dryden's defence of rhyming verse of drama in his dedicatory epistle to The Rival Ladies (1664). Dryden came back to the topic in his Essay of Dramatic Poesy (1668). Howard responded in his 1668 preface [to The Great Favourite, or the Duke of Lerma], and Dryden rounded off the exchange in his Defence of an Essay of Dramatic Poesy (1668)" (Blamires, 1991, p. 84). Actually, the preface was the favourite form given by the writer-critics to their critical commentary on drama, among whom, apart from Howard, being Richard Flecknoe and Thomas Shadwell.

Distinguished by both verse structure and subject matter from the comedy of manners, the heroic drama is composed in heroic verse (closed couplets in iambic pentameter) and focuses on subjects related to national history, mythological events, or other important matters, and the hero is of epic significance, powerful and decisive, and often torn between passion and honour. This type of tragedy is characterised by bombastic dialogue, excessive spectacle, elaborate scenery, and grand action, usually the conquest of a country. The term "heroic drama" was invented by John Dryden for his play entitled The Conquest of Granada (1670), in whose Preface to the printed version, Dryden developed a series of rules for this type of drama, arguing that drama was a species of epic poetry for the stage, and that the heroic drama was to other plays what the epic was to other poetry. "Heroic drama" is a form of tragedy, "drama in the epic mode - grand, rhetorical and declamatory; at its worst, bombastic. Its themes were love and honour and it was considerably influenced by French classical drama, especially by the work of Corneille" (Cuddon, 1992, p. 408).

The attempt of Dryden and his followers to produce a dramatic entertainment about the serious subjects of national history and the failure of the dramatists to create credible powerful and military dominating heroes were the reasons of the attacks on the heroic drama by, among others, George Villiers, the second Duke of Buckingham, whose satire The Rehearsal was successful enough to make the heroic drama largely disappear from English literary scene. 
Although Restoration drama aimed at reviving and imitating Elizabethan dramatic tradition, it actually manifested a violent break with Elizabethan drama in matters of both thematic context and theatrical representation, and even concerning the size of the theatre.

Unlike drama, the poetry of the Restoration period did not manifest such a violent break with Elizabethan tradition. The metaphysical style that dominated the poetic production of the first half of the seventeenth century was largely a continuation of certain conflicts that began to disturb the Elizabethan status quo, and continued to influence the poetry of the Restoration period, which relied on concentration and straightforwardness, paradox and antithesis. There was the search for the "golden mean" that starting with the Restoration period would juxtapose the internal conflicts of the metaphysical poets upon the philosophical certainties and satirical comments in the poetry of some neoclassical writers of the late seventeenth century and the next eighteenth century.

On the other hand, the rising in Restoration neoclassical spirit manifested as a strong reaction against the cultural extravagances of the Baroque and metaphysical poetry. Instead, it revived and institutionalized the classical principles, a fact which makes Restoration, the last part of the seventeenth century, to be the first of the three parts of the neoclassical period in British literature. As a part of British neoclassicism, the Restoration period was followed by the "Augustan Age" (also referred to as the "Age of Reason") in the first half of the eighteenth century, and by the "Age of Johnson" that between 1750s and 1780s represented the decline of neoclassicism. The eighteenth century in general is called the "Age of Enlightenment", a term often used to name also most of the eighteenth century Britain, including the "Augustan Age" and the "Age of Johnson" which came before Romanticism.

In English culture, "Enlightenment" and "neoclassicism" cover almost the same period and are almost synonymous, the main difference being that the former is a philosophical movement, whereas the latter refers mainly to literary theory and practice. In rest, similar to the neoclassical movement, the Enlightenment

celebrated reason, the scientific method, and human being's ability to perfect themselves and their society. It grew out of a number of seventeenth century intellectual attainment: the discoveries of Sir Isaac Newton, the rationalism of Descartes and Pierre Bayle, and the empiricism of Francis Bacon and John Locke. The major champions of its beliefs were the philosophers, who made a critical examination of previously accepted institutions and beliefs from the viewpoint of reason and with confidence in natural laws and universal order (Holman \& Harmon, 1992, p. 169).

The beginnings of the Enlightenment and neoclassicism in British cultural background, which took place during the Restoration period as the result of some major Continental influences, were also the direct consequences of some major changes in the native literary taste which occurred in that period. Neoclassical doctrine itself should be regarded primarily as a new literary attitude that came to influence the rise of the English novel in the eighteenth 
century and to dominate the poetic production. Neoclassicism was actually expressed in poetry for over a hundred years during the late seventeenth century (represented at best by Dryden) and most of the eighteenth century (dominated by the work of Pope and Johnson).

\section{The Writer-Critic John Dryden}

John Dryden as a poet, dramatist and literary critic would dominate the literary efforts of the Restoration period and of English neoclassicism at its beginnings. The dominance was strong in spite of the many contemporary attacks from, among others, Gerald Langbaine (1657-1692) in An Account of the English Dramatick Poets (1691) on grounds of plagiarism. Dryden's importance as comic dramatist is rather small compared to that of a man of letters and poet, and much of the importance of Dryden's poetry lies in his occasional pieces. As a poet, Dryden is totally impersonal; he is not concerned with personal feelings but achieves a poetic comment on matters of public concern, writing at best in the tradition of verse compliment, in addressing particular people on particular occasions. And it was not in drama but in poetry and, especially, in literary criticism that Dryden established a pattern of writing and a number of theoretical principles that determined the character of neoclassical doctrine and literature in the next century. He created a new style in prose and poetry that influenced, among others, Alexander Pope, the most brilliant writer among the Augustans.

One of the major proponents of the classical ideas into England during the Restoration period, John Dryden was the most prolific English writer of the second half of the seventeenth century, but he was chiefly acclaimed for being a prominent literary critic, as Samuel Johnson did in Prefaces, Biographical and Critical, to the Works of the English Poets:

Dryden may be properly considered as the father of English criticism, as the writer who first taught us to determine upon principles the merit of composition. Of our former poets, the greatest dramatist wrote without rules, conducted through life and nature by a genius that rarely misled, and rarely deserted him. Of the rest; those who knew the laws of propriety had neglected to teach them. (...) Two Arts of English Poetry were written in the days of Elizabeth by Webb and Puttenham, from which something might be learned, and a few hints had been given by Jonson and Cowley; but Dryden's An Essay of Dramatic Poesie, was the first regular and valuable treatise on the art of writing.

This passage shows that Dryden was probably the first to write a treatise, that is, Of Dramatic Poesie, An Essay, on the art of writing in a systematised way. Dryden's critical masterpiece, which was written to prescribe the ways authors should follow in writing after recovering themselves from Puritanism, also defends and compares English literature in relation to the general European one, and, in particular, to the recent French drama. The work proves the excellence of English literature in the general literary background of Europe. Imitating Plato in its form, Dryden's critical text is written as a fictitious dialogue, a formal debate on drama among four characters placed in a boat on the Thames 
and hearing the noise of a naval battle, probably an English victory over Dutch army in 1665, which offers a sense of patriotic pride to the context. Also, in the course of critical debate, the character called Neander ("the new man") - the voice of Dryden himself and as such the defender of English drama - argues in favour of a national, English literary tradition: for instance, when asked by Eugenius, Neander states, at the beginning of his discussion on English playwrights Shakespeare, Beaumont, Fletcher, and Jonson, that in doing so "I shall draw a little envy upon my self", and, after arguing in favour of their value, he claims that "we have as many and profitable Rules for perfecting the Stage as any wherewith the French can furnish us".

Nender represents English literature and defends the native dramatic practice of the recent past, in particular English tragicomedy, as well as the rhymed heroic drama, which Dryden considers to be the greatest achievement of English drama. Apart from Neander, there are three other characters as speakers in the essay. Of course, such debates could not actually take place, but each speaker can be identified with a contemporary person, and certainly each has his own topical concern to discuss and defend in front of the others. Crites, whose name suggests a critical mind, and who was modelled after Dryden's collaborator and brother-in-law Sir Robert Howard, defends ancient dramatic tradition and clarifies the rules of the unities of time, place, and action. Eugenius, whose name means "well-born", refers to the famous Cavalier poet Lord Charles Sackville. He defends the moderns against the ancients on the grounds of scientific progress that makes poetry attain greater excellence. Lisideus, whose name is a Latinised anagram of "Sedley", is Sir Charles Sedley; he defends the recent French dramatic practice, which, due to Richelieu's protection of arts, has reached almost perfection by keeping the rules, measure, and order, and by using rhyme instead of blank verse. For Lisideius, and for Dryden himself, ancient theories are no less viable. For instance, Lisideius defines a play as "a just and lively image of human nature, representing its passions and humours, and the changes of fortune to which it is subject; for the delight and instruction of mankind". The first part of the definition clearly derives from Aristotle's Poetics and the last clause derives from Horace's Ars Poetica.

The perspective of binary oppositions - moderns against ancients (Eugenius versus Crites) and English against French (Neander versus Lisideius) - is congenial for embarking on a critical debate about drama in general, types of drama, and thematic and structural particularities of drama from four different perspectives. However, Neander turns from a general discussion and defence of English drama to a critical, and, at certain moments, comparative appreciation of Renaissance playwrights, in particular Shakespeare and Jonson. Dryden first considers Fletcher and Beaumont, but briefly, his main attention being devoted to Shakespeare and Jonson. For Dryden, Shakespeare has "the largest and most comprehensive soul"; he is naturally gifted, the greatest of all writers, following in general but also breaking some of the Aristotelian and Horatian "rules", and thus combining in his works both the innovative spirit of the Renaissance and 
the revival of ancient classical models. When compared to Shakespeare, Jonson is "the most learned and judicious writer" which any theatre ever had, and, being "deeply conversant in the Ancients, both Greek and Latin", Jonson borrowed boldly from the ancient writers and faithfully followed the classical doctrine. Related to Jonson, these characteristics are nothing but some of the main principles of neoclassicism.

Finally, when comparing the two playwrights, Dryden concludes that Jonson is "the more correct Poet, but Shakespeare the greater wit. Shakespeare was the Homer or father of our dramatic poets; Jonson was the Virgil, the pattern of elaborate writing; I admire him, but I love Shakespeare".

In the Restoration period, following the Puritan Commonwealth, Dryden defined drama as "a just and lively image of human nature" and assumed in his critical text the task to defend and revive English drama. In this respect, the task means to prescribe the future ways of literary development based on the great predecessors, on the best dramatic tradition of Renaissance playwrights, namely Shakespeare and Jonson. Dryden is on the side of the moderns who have excelled the ancients in tragedy. In A Discourse Concerning the Original and Progress of Satire (1693) Dryden claims that the moderns have excelled the ancients in satire as well. This work is considered inferior to his essay, being his "longest piece of criticism" which, of all his works, "is the most heavily loaded with scholarship: all second-hand and acknowledged" (Sambrook, 2005, p. 89).

As the Restoration period marked the beginnings of neoclassicism in English literature, Dryden's contribution to that was immense, and he is commonly approached as the first of English neoclassicists. Dryden was the most prolific author of the Restoration, truly a writer-critic who "embodies the spirit and ideas of the neoclassical period, the literary age that follows Sidney and the Renaissance" (Bressler, 2007, p. 31). Apart from being theoretical, Dryden's literary criticism reveals a relative fidelity to classics of a critic who may be considered to be "a pragmatic or liberal neoclassical critic", since he accepts the theoretical patronage of Aristotle and Horace, but allows for exceptions and agrees with those moderns who feel "free to improve upon it [the ancient model] when situation demands" (Dutton, 1984, p. 36). Still, Dryden remains in spirit neoclassical, invoking in his defensive and prescriptive criticism the ancient classical "authorities" with their prescriptions and rules.

One may notice Dryden's adherence to classical inheritance in his admiration for Jonson and his thorough critical appreciation of Jonson, as compared to the more general and superficial one of Shakespeare, which shows that for Dryden Jonson is a kind of prototype found in the Renaissance of a complete neoclassical man, whose plays should be taken as models of dramatic writing.

Dryden's Of Dramatic Poesie, An Essay, with its dramatic structure and critical focus on particular writers and literary works - the treatise also revealing the major aspects of the ancient Greek and Latin, and the modern English and French drama - appears to be less theoretical than practical in a period 
(Restoration) of consolidation of neoclassical principles that were to dominate English art and criticism for over a century preceding the rise of Romanticism in the 1780s. Concerning the main aspects of Restoration literature and thought, there was, according to Andrew Sanders, the necessity of a tradition "to be reestablished which was both responsive to the recent past and a reflection of new tastes and fashions" (Sanders, 1994, p. 266). In this respect, it was John Dryden who, in his celebrated Of Dramatic Poesie, An Essay, combined dramatic expression and practical criticism, and pleaded for European recognition of his native literature and for the synchronization of British with the general European literature. He clearly prescribed to his fellow writers the classical and contemporary, in particular French, doctrines to be followed in thought and Elizabethan drama of Shakespeare and Jonson to be revived and the contemporary European models to be imitated in literature.

The growth of British literature in the next eighteenth century reveals that the first aspect was a triumphant accomplishment, since it successfully came to dominate as neoclassicism the English cultural background for a long period that ended around the $1780 \mathrm{~s}$. Concerning the second aspect, the writers of Restoration attempted to recapture the status of drama as a major literary tradition, and produced a huge amount of dramatic works. However, they never succeeded in reviving it, the eighteenth century British literature consisting mainly in neoclassical and later pre-Romantic poetry, and at the same time witnessing the rise of the English novel. The next eighteenth century highly valued Dryden's contribution to critical writing, being considered by Dr Samuel Johnson to be the best English literary critic. Although in some degree neglected by Romanticism and its aftermath, in the twentieth century, T. S. Eliot, another great writer-critic, praises Dryden and considers his work to be "the first serious literary criticism in English by an English poet"; likewise, David Daiches, another important critic, considers him to be "the true father of English practical criticism".

\section{Practical Argumentation: A Fragment from John Dryden's Of Dramatic Poesie, An Essay:}

As Neander was beginning to examine The Silent Woman, Eugenius, looking earnestly upon him; "I beseech you Neander", said he, "gratifie the company and me in particular so far, as before you speak of the Play, to give us a Character of the Authour; and tell us franckly your opinion, whether you do not think all Writers, both French and English, ought to give place to him".

"I fear", replied Neander, "that in obeying your commands I shall draw a little envy upon my self. Besides, in performing them, it will be first necessary to speak somewhat of Shakespeare and Fletcher, his Rivalls in Poesie; and one of them, in my opinion, at least his equal, perhaps his superior. (...)

To begin then with Shakespeare; he was the man who of all Modern, and perhaps Ancient Poets, had the largest and most comprehensive soul. All the Images of Nature were still present to him, and he drew them not laboriously, but luckily: when he describes any thing, you more than see it, you feel it too. Those who accuse him to have 
wanted learning, give him the greater commendation: he was naturally learn'd; he needed not the spectacles of Books to read Nature; he look'd inwards, and found her there. I cannot say he is every where alike; were he so, I should do him injury to compare him with the greatest of Mankind. He is many times flat, insipid; his Comick wit degenerating into clenches; his serious swelling into Bombast. But he is alwayes great, when some great occasion is presented to him: no man can say he ever had a fit subject for his wit, and did not then raise himself as high above the rest of the Poets (...)

As for Jonson, to whose Character I am now arriv'd, if we look upon him while he was himself, (for his last Playes were but his dotages) I think him the most learned and judicious Writer which any Theater ever had. He was a most severe Judge of himself as well as others. One cannot say he wanted wit, but rather that he was frugal of it. In his works you find little to retrench or alter. Wit and Language, and Humour also in some measure we had before him; but something of Art was wanting to the Drama till he came. He manag'd his strength to more advantage then any who preceded him. You seldome find him making Love in any of his Scenes, or endeavouring to move the Passions; his genius was too sullen and saturnine to do it gracefully, especially when he knew he came after those who had performed both to such an height. Humour was his proper Sphere, and in that he delighted most to represent Mechanick people. He was deeply conversant in the Ancients, both Greek and Latine, and he borrow'd boldly from them: there is scarce a Poet or Historian among the Roman Authours of those times whom he has not translated in Sejanus and Catiline. But he has done his Robberies so openly, that one may see he fears not to be taxed by any Law. He invades Authours like a Monarch, and what would be theft in other Poets, is onely victory in him. With the spoils of these Writers he so represents old Rome to us, in its Rites, Ceremonies and Customs, that if one of their Poets had written either of his Tragedies, we had seen less of it then in him. If there was any fault in his Language, 'twas that he weav'd it too closely and laboriously in his serious Playes; perhaps too, he did a little to much Romanize our Tongue, leaving the words which he translated almost as much Latine as he found them: wherein though he learnedly followed the Idiom of their language, he did not enough comply with ours. If I would compare him with Shakespeare, I must acknowledge him the more correct Poet, but Shakespeare the greater wit. Shakespeare was the Homer, or Father of our Dramatick Poets; Jonson was the Virgil, the pattern of elaborate writing; I admire him, but I love Shakespeare. To conclude of him, as he has given us the most correct Playes, so in the precepts which he has laid down in his Discoveries, we have as many and profitable Rules for perfecting the Stage as any wherewith the French can furnish us.

John Dryden, the second in the line of the most prominent English literary critics, represents the Restoration period in the history of English literary criticism, and, like Sidney's critical work, Dryden's Of Dramatic Poesie, An Essay reveals the condition of the contemporary to him literature. Written in the dialogue form borrowed from Plato, Dryden introduces in his text four characters as speakers, who represent ancient Greek drama (Crites) versus modern literary tradition (Eugenius), and the contemporary French dramatic practice (Lisideus) versus English literary practice (Neander). The voice of Dryden in the text is Neander, who, in the chosen fragment, expresses critical ideas by comparing Jonson and Shakespeare, the two most important English Renaissance writers. 
Working on the seventeenth century concept of "wit" as the writer's creative power, imaginative flight, and the ability to create unexpected imagery, literature of high aesthetic status, Dryden embarks on a comparative critical evaluation of William Shakespeare and Ben Jonson, startling in its approach and concluding reflections.

John Dryden's criticism on Shakespeare reveals, actually, only two directions of approach: first, that the great Renaissance writer is a complete Renaissance man, having "the largest and most comprehensive soul", and, second, that Shakespeare is the greatest wit.

About Jonson, Dryden is able to identify more characteristics, namely that Jonson is (1) subject to training, rules and discipline: "the most learned and judicious Writer which any Theatre ever had", "a most severe Judge of himself as well as others"; (2) promoter of common sense and measure, using to a lesser degree the imaginative faculty, or "wit": "one cannot say he wanted wit, but rather that he was frugal of it"; (3) rational, "saturnine" and less expressive of feelings: "you seldom find him making Love in any of his Scenes, or endeavouring to move the Passions; his genius was too sullen and saturnine to do it gracefully"; (4) satirical in his work: "humour was his proper Sphere, and in that he delighted most to represent Mechanick people"; and (5) educated in the spirit of the ancient tradition and imitative of the ancient models: "he was deeply conversant in the Ancients, both Greek and Latine, and he borrowed boldly from them".

What appears strange and surprising is the subjective and, at the same time, superficial criticism on Shakespeare as compared to the more objective and profound approach to Jonson. In this, one can easily notice that Dryden's preference is for Jonson, "the more correct poet". The Restoration critic Dryden concentrates more on Jonson than on Shakespeare and his critical ideas on Jonson are more systemic and comprehensive than those on Shakespeare.

The question is, then, what has determined Dryden to follow this critical path if in the history of British literature William Shakespeare is considered to be a more important writer than Ben Jonson. Dryden, certainly, does not deny Shakespeare's status, the greatest of English writers, for whom he claims to feel sincere love, but Jonson is a no less important writer, for whom Dryden expresses his sincere admiration:

If I would compare him [Jonson] with Shakespeare, I must acknowledge him the more correct Poet, but Shakespeare the greater wit. Shakespeare was the Homer, or Father of our Dramatick Poets; Jonson was the Virgil, the pattern of elaborate writing; I admire him, but I love Shakespeare.

In these different attitudes, and especially in considering Restoration - the period in which Dryden wrote his critical text - as the period offering the beginnings of neoclassicism in England, one can find the answer to the question of what might have been the reason for Dryden's critical emphasis on Jonson rather than on Shakespeare. 
Moreover, by realising that the characteristics of Jonson, as presented by Dryden, are clear aspects and major principles of the neoclassical doctrine which is on its way of being implemented in the English cultural background, one may easily give the answer by saying that Dryden finds and promotes Jonson as an admirable and perfect model found in the Renaissance of a complete neoclassical writer.

In more general terms, it is clear again that John Dryden, in his Of Dramatic Poesie, An Essay, a work of art in itself, pleading for European recognition of his native literature and for the synchronization of British with the general European literature, prescribes with full judicious detachment and openmindedness to his fellow writers the ancient classical and contemporary, in particular French, doctrines to be followed in thought and Elizabethan drama of Shakespeare and especially Jonson to be revived, and along with the contemporary European models, to be imitated in literary practice. In this respect, one might consider Dryden's critical discourse to be first of all prescriptive, then dependent on and highly expressive of its literary period, Restoration, as the first part of the larger neoclassical age.

Dryden's criticism is also to be viewed as defensive and subjective. And what he defends through the lens of subjectivity is his national literature, the great aesthetic values of the literary work of Shakespeare and Jonson. This is expressed, among other things, through a sense of national pride revealed at the beginning of the fragment, in Neander's affirmation that "in obeying your commands I shall draw a little envy upon my self", and at the end of it when Neander claims that "we have as many and profitable Rules for perfecting the Stage as any wherewith the French can furnish us".

\section{Other Samples of Prescriptive Criticism in the Age of Neoclassicism: $A n$ Essay on Criticism and An Essay on Man by Alexander Pope}

In the field of literary ideas, the first half of the eighteenth century was dominated by the neoclassical ideas expressed by Alexander Pope in the didactic poem An Essay on Criticism and the philosophical poem An Essay on Man.

The first half of eighteenth century in English literature, known as the Augustan Age, illustrates the classical views on art and literature at the highest point of their dominance. Especially for poetry, rational approaches and points of view were developed as based on models of Greece and Rome and involving absolute rules and principles to be followed in the critical judgement of literature. The Augustans developed an aesthetic theory and a type of textual criticism which became more scientific, criticism as "Nature methodized", in Pope's terms, criticism bound to the normative principles of decorum and poetic diction, and those of imitating nature and the ancients. "Follow nature and imitate the classics" is what Pope proclaimed, along with the emphasis on the power of reason, rule, common sense, measure, order, imitation, respect to genre and the unities, emphasis on the "sublime", while rejecting emotion and imagination. 
As in earlier criticism, poetry receives a complex theory involving the rules of poetic composition, the principles of poetic structure, and the object of poetry as pleasurable instruction. In this respect, the most revelatory would be Alexander Pope's An Essay on Criticism, "an exercise in aphoristic verse discourse which presents criticism as a disciplined extension of common sense, clearheadedness, and neoclassical good manners" (Sanders, 1994, p. 289). An Essay on Criticism represents a discussion in verse form, based on neoclassical doctrines, in which the emphasis is placed on rules, order, and good taste, which should govern poetic composition and lead it to affirm or rather re-affirm absolute truths which have already been expressed by ancient classical poets.

The task of literary criticism would be, then, to defend, sustain, and strengthen the classical values and to follow the critical tradition as established by the ancients. The essay is addressed to critics rather than to the poets, but Pope prescribes rules to both critics and poets, of which the highly emphasised ones include decorum and poetic diction, personification of abstractions, and consolidation of the heroic couplet as the main principle for versification. A recurrent image in Pope's treatise is the conflict between the critic, whom Pope apparently sides with, and the poet: the former imposes rules on poets and judges them according to some strict regulations, whereas the latter attempts to flee from the normative prescription. Pope asks for a close relationship between the two: "A perfect judge will read each work of wit/With the same spirit that its author writ".

Written by Pope in his earliest years, the essay does not provide an original contribution to literary theory, or to the philosophical background of his period, as his later An Essay on Man would, except that it is addressed to critics rather than the poets, and, even so, the text often shifts its concern from criticism to poetry and vice versa. However, having nothing original in point of the neoclassical doctrine, one should consider at least the fact that the poem attempts to discuss the validity of this doctrine by combining in one poetic discourse the exposition of the theoretical principles and the creation of a literary text based on such principles. A young person in his twenties, Pope longs to display his learning and be didactic and moralising, his An Essay on Criticism suggesting a kind of "critical ethic", as Geoffrey G. Harpham calls it. In this respect, based on the negation of subjective impulses, the true criticism, according to Pope, is natural, modest, moderate, and just, resulting not only "from cognitive superiority or acquired learning, but first and foremost from a certain kind of virtue" (Harpham, 2001, p. 373). Likewise earlier, while defending poetry in neo-Horatian terms as a kind of writing that teaches and delights, Sidney valued the ethical value of virtue but in relation to poetry not criticism. For him, poetry is a superior form of ethics, or rather above philosophy and ethics itself, since it both teaches and moves to virtue as "a divine force, far above man's wit".

Pope's criticism is called "ethical humanism", a common feature of the most of the eighteenth century critical thought, in that it explores not only the mind of 
the poet, but also his conditions and environment, as Pope himself declares that the critic should learn the writer's "Fable, Subject, scope in every page;/Religion, Country, genius of his Age". An Essay on Criticism, clearly inspired from Horace's Ars Poetica, discusses the principles of poetic art, didactically prescribes the rules of writing and criticising, states the authority to be attributed to the ancient writers, and gives a famous definition of the neoclassical "wit":

True wit is nature to advantage dressed,

What oft was thought, but never so well expressed;

Something whose truth convinced as sight we find,

That gives us back the image of our mind.

In short, the rules for criticism and literary practice, as prescribed by Pope, can be summed up as "follow Nature and imitate the Classics":

First follow Nature, and your judgement frame

By her just standard, which is still the same;

Unerring Nature, still divinely bright,

One clear, unchanged, and universal light,

the meaning of "Nature" referring here not to wilderness and mysteries of the world, as for Romantics, but to order and common sense. The ancients are to be followed because they based their ideas on Nature, whom they "methodized" and whose laws they discovered and defended:

Those rules of old discovered, not devised,

Are Nature still, but Nature methodized;

Nature, like liberty, is but restrained

By the same laws which first herself ordained.

In this respect, "by affirming the imitation of the classical writers and through them of nature itself and by establishing the acceptable or standard criteria of poetic language, Pope grounds his criticism in both the mimetic (imitation) and rhetoric (patterns of structure) literary theories" (Bressler, 2007, p. 34-35). Indeed, in the Renaissance and afterwards, for nearly until the second half of the eighteenth century, the major critical voices revived, reinforced and reshaped the classical tradition along with a strong emphasis on following the classical rules and imitating the laws of nature, as in Ben Jonson's Timber: Or Discoveries, Pierre Corneille's Discours, Boileau's L'Art Poetique, and Alexander Pope's An Essay on Criticism. Like Sidney and Boileau, Pope requires the poet to be a natural genius, possess knowledge of the artistic rules, acquire an education based on the classics, and imitate the classic models.

An Essay on Man, another major work by Pope, consists of a "Design" in prose followed by four epistles in verse form addressed to Henry St. John, Viscount of Bolingbroke, a leading Tory figure and himself a writer of philosophical and political essays. The poem is designed as a philosophical work focused on the task "to vindicate the ways of God to Man". It largely draws on the poet's 
personal understanding of the philosophy of Leibnitz, and examines the human condition against Miltonic, cosmic background. One may hardly argue that $A n$ Essay on Man is focused on commonplace and the ordinary aspects of everyday life, as the poem is full of many and often disputable doctrines, where the philosophical speculation is dramatic and concrete, the ideas being transmitted in witty couplets by attractive wording.

In discussing human condition and human nature, Pope ignores the view that the world is not perfect but fallen, and that men are free agents responsible for their actions. Instead, Pope attempts to prove that everything is well in the best of the possible worlds, that the scheme of the universe is the best of all possible schemes, and that people's failure to see the perfection is caused by their limited vision.

The evil exists in the world, but is limited and partial, as "Partial Ill" is but a part of "Universal Good", and, in order to achieve happiness and reach perfection, the human being should transcend the self-love towards social-love and then to the love for God, where "self-love and social" "All are but parts of a stupendous whole,/Whose body Nature is, and God the soul".

In order to see the prescriptive nature of Pope's An Essay on Man, the following fragment would be revelatory:

Having proposed to write some pieces on human life and manners, such as (to use my lord Bacon's expression) came home to men's business and bosoms, I thought it more satisfactory to begin with considering Man in the abstract, his nature and his state; since, to prove any moral duty, to enforce any moral precept, or to examine the perfection or imperfection of any creature whatsoever, it is necessary first to know what condition and relation it is placed in, and what is the proper end and purpose of its being.

The science of human nature is, like all other sciences, reduced to a few clear points: there are not many certain truths in this world. It is therefore in the anatomy of the mind as in that of the body; more good will accrue to mankind by attending to the large, open, and perceptible parts, than by studying too much such finer nerves and vessels, the conformations and uses of which will for ever escape our observation. The disputes are all upon these last, and I will venture to say, they have less sharpened the wits than the hearts of men against each other, and have diminished the practice, more than advanced the theory of morality. If I could flatter myself that this Essay has any merit, it is in steering betwixt the extremes of doctrines seemingly opposite, in passing over terms utterly unintelligible, and in forming a temperate yet not inconsistent, and a short yet not imperfect, system of ethics.

This I might have done in prose; but I chose verse, and even rhyme, for two reasons. The one will appear obvious; that principles, maxims, or precepts so written, both strike the reader more strongly at first, and are more easily retained by him afterwards: the other may seem odd, but it is true; I found I could express them more shortly this way than that much of the force as well as grace of arguments or instructions depends on their conciseness. I was unable to treat this part of my subject more in detail, without becoming dry and tedious; or more poetically, without sacrificing perspicuity to ornament, without wandering from the precision, or breaking the chain of reasoning. If 
any man can unite all these without any diminution of any of them, I freely confess he will compass a thing above my capacity.

What is now published is only to be considered as a general map of Man, marking out no more than the greater parts, their extent, their limits, and their connection, but leaving the particular to be more fully delineated in the charts which are to follow. Consequently, these Epistles in their progress (if I have health and leisure to make any progress) will be less dry, and more susceptible of poetical ornament. I am here only opening the fountains, and clearing the passage. To deduce the rivers, to follow them in their course, and to observe their effects, may be a task more agreeable.

The above selected fragment represents The Design, that is, the introductory part, of An Essay on Man, which is followed by the four epistles written in verse form. The Design contains some ideas on poetry expressed through the argumentation of the reasons for which Pope has chosen the poetic form for his philosophical work.

First, poetry has stronger effects on the reader leading to a better understanding of the poet's message: "strike the reader more strongly at first". Second, the poetic form is characterized by concision, as it "could express them [ideas] more shortly this way than in prose". Finally, as a neoclassical writer, Pope accepts the necessity of poetic diction and decorum in a poetic text, but the use of ornamentation must not affect the reasonable, concise expression of ideas: "perspicuity" must not be sacrificed to "ornament" and the poet must not be "wandering from the precision, or breaking the chain of reasoning".

In that, one may easily see again Pope expressing, advocating, and promoting the neoclassical principles concerning poetry writing, which makes his ideas on literature, as little as they are stated in the Design and scattered throughout the epistles, to be highly dependent on and expressive of the dominant doctrine of the period, as well as prescriptive, and to a lesser degree defensive and subjective.

Apart from the Design, throughout the entire poem, Pope's literary theory and practice, as combined in one verbal discourse, reveal a poet focused on expressing and prescribing rules not so much on poetic composition but existence in general, expressing the optimism and self-confidence of an urban society pleased with its own civilization. At moments, however, the optimism in An Essay on Man co-exists with a satirical resentment as two facets reflecting the inner contradictions of the poet and those of the period itself.

\section{Conclusion}

Like in earlier periods, in general in the seventeenth century, including the Restoration period, and later throughout the eighteenth century, criticism was still far from focusing on particular authors and texts, that is, far from dealing with literature as we understand nowadays to be the aims and concerns of literary criticism.

Instead, the criticism of those centuries, "based on classical models, dealt mainly with literature-related theoretical prescriptiveness" and the issue of 
genres (Urnov, 1979, p. 5). The privileged ones remained to be poets; dramatists were placed next to them, whereas the rising in the eighteenth century novelists were disconsidered. Dryden debated on drama. Addison wrote on tragedy, on lyric and epic poetry, and on imagination and literature in general. Johnson wrote his Lives of the Poets in such a manner as if there were no contemporary novelists, even though Johnson himself played with fiction in Rasselas and showed a high estimate for this genre.

There was then the task assumed by the practitioners, the novelists themselves (Defoe, Richardson, and Fielding), to evaluate their own writings and promote them as a new and distinct genre of novel.

Apart from these critical perspectives, there were also debates on ancients and moderns as a "battle of the books" (Reynolds, Temple, and Swift), on morality and literature (Mulgrave, Wolseley, Collier, and Congreve), on beauty in poetry (Hutcheson) and on the status and subjects of poetry (Thomson). Criticism assumed also other tasks, such as to advocate and institutionalize neoclassicism (Dryden, Pope, and Johnson), or the rejection of neoclassicism (Warton, Young, and Lowth), and even the concern with the status and role of the critic and criticism (Addison, Pope, and Hume). The diversity of critical concerns paralleled the diversity of the form of the critical texts, ranging from verse and dialogue to essay and preface. Amid general theorisation and abstract debates on literary issues, there were some concerns with particular writers, such as Peacham, Dryden, Dennis, Johnson, and Fielding.

John Dryden, who introduced the term "criticism" as early as 1677 , represents after Sir Philip Sidney the second important step forward in English literary criticism with his Of Dramatic Poesie, An Essay. Among other things, Dryden succeeds to employ a variety of critical perspectives from ancient to contemporary French and unite them under the form of a natural, almost modern prose style. Above all, Dryden avoids the moral or theological assessment of literature and focuses on the literary practice of certain writers, in particular the comparative assessment of Shakespeare and Jonson, a recurrent theme in literary criticism, whom he prescribes as literary models.

In the eighteenth century, the theoretical principles of neoclassicism enjoyed their highest reputation as set forth by Alexander Pope in prefaces, An Essay on Criticism, and An Essay on Man. Alexander Pope was the dominant figure among neoclassical writers, his theoretical contribution and poetical practice exemplifying in the best way neoclassical optimism, self-confidence and urbanism in an age pleased with its civilization. Pope also aptly expresses neoclassical emphasis on reason, order, common sense, rules in the creation of poetry, and imitation of the classics and the laws of nature, as in An Essay on Criticism and An Essay on Man. The former reveals, actually, Pope's status as a neoclassical literary critic, but, being written by Pope in his earliest years of literary activity, this work does not provide an original contribution to literary theory, except the fact that it is addressed to critics and that it combines in one 
poetic discourse the theoretical ideas of neoclassical doctrine with the creation of a literary text based on such ideas.

This is also the principle of composition of a more original work which is the philosophical poem An Essay on Man. Like the previous one, this work displays Pope's alliance to neoclassical doctrine and the principles of "imitate the classics" and "follow the nature", as well as his wide knowledge and intellectual brightness combined with a dynamic literary expression.

During the neoclassical period, the most important and influential critical voices belong to Dryden and Pope, who, together with Johnson, were the true theoreticians and practitioners of neoclassicism, aiming at defining the present and future ways of English poetry by offering prescriptive definitions, and thus their criticism being, in this respect, apart from reflecting the neoclassical mentality, normative and prescriptive.

\section{REFERENCES}

Blamires, H. (1991). A History of Literary Criticism. London: Macmillan.

Bressler, C. E. (2007). Literary Criticism: An Introduction to Theory and Practice $\left(4^{\text {th }}\right.$ ed.). Englewood Cliffs: Prentice-Hall Inc.

Ceuca, J. (2002). Evoluţia formelor dramatice. Cluj-Napoca: Dacia.

Clement, B. (2000). Tragedia clasică. Iaşi: Institutul European.

Cuddon, J. A. (1992). The Penguin Dictionary of Literary Terms and Literary Theory. London: Penguin Books Ltd.

Dutton, R. (1984). An Introduction to Literary Criticism. London: Longman.

Frank, M. (2002). Gender, Theatre, and the Origins of Criticism: From Dryden to Manley. Port Chester: Cambridge University Press.

Graf, A. (1997). Marile curente ale filosofiei moderne. Iaşi: Institutul European.

Hampshire, S. (Ed.) (1956). The Age of Reason: The $17^{\text {th }}$ Century Philosophers. New York: The New American Library.

Harpham, G. G. (2001). Ethics and literary criticism. In C. Knellwolf \& C. Norris (Eds.), The Cambridge History of Literary Criticism, Volume 9: Twentieth Century Historical, Philosophical and Psychological Perspectives (pp. 371-385). Cambridge: Cambridge University Press.

Heidegger, M. (1971). Poetry, Language, Thought. New York: Harper and Row.

Highet, G. (1976). The Classical Tradition: Greek and Roman Influences on Western Literature. Oxford: Oxford University Press.

Holman, C. H., \& Harmon, W. A. (1992). A Handbook to Literature. New York: Macmillan.

Munteanu, R. (1989). Farsa tragic. Bucureşti: Univers. 
Sambrook, J. (2005). Poetry, 1660-1740. In H. B. Nisbet \& C. Rawson (Eds.), The Cambridge History of Literary Criticism, Volume 4: The Eighteenth Century (pp. 75-116). Cambridge: Cambridge University Press.

Sanders, A. (1994). The Short Oxford History of English Literature. Oxford: Oxford University Press.

Stephen, M. (1984). An Introductory Guide to English Literature. London: Longman.

Urnov, D. M. (Ed.). (1979). The Idea of Literature: The Foundations of English Criticism. Moscow: Progress Publishers.

Vickers, B. (1996). The Seventeenth Century. In P. Rogers (Ed.). The Oxford Illustrated History of English Literature (pp. 160-213). Oxford: Oxford University Press.

\title{
JOHN DRYDEN, RESTORATION, AND NEOCLASSICISM: SAMPLES OF PRESCRIPTIVE CRITICISM IN ENGLISH LITERATURE
}

\begin{abstract}
Literary criticism implies the intellectual capacity to evaluate and understand the literary text, the analysis of particular works being the main aim of literary criticism, but, though achieved by most of the critics prior to the twentieth century, in English background criticism has started with some purposes which are alien to the nature of critical act. For instance, Sydney defends, Dryden prescribes, Pope reflects and prescribes, Fielding introduces a new genre and Wordsworth a new type of poetry, etc. English criticism during the neoclassical period was a complex and multi-voiced phenomenon, represented by a large number of critics and writer-critics who developed a reflexive but above all normative and prescriptive critical discourse. John Dryden and his $O f$ Dramatic Poesie, An Essay would better show the condition of English criticism in Restoration. The first half of the eighteenth century was dominated by the neoclassical ideas expressed by Alexander Pope in $A n$ Essay on Criticism and An Essay on Man; the second half of the century was governed by the personality of Dr Samuel Johnson and his influential Lives of the Poets and Dictionary of the English Language. The most prescriptive critical voice in English literature belonging to the neoclassical period is that of John Dryden, as to be equalled perhaps only by Alexander Pope. To reveal the essence of prescriptive criticism as explaining and giving rules as well as showing the direction for literary production with regards to the critical discourse of Dryden and that of Pope represents the purpose of this study.
\end{abstract}

Keywords: Restoration, Neoclassicism, Literary Criticism, Literary Theory, Prescriptive Criticism, Critic, Writer-Critic. 